\title{
Vegetation differentiation and secondary succession on abandoned agricultural large-areas in south-eastern Poland
}

\author{
Beata Barabasz-Krasny
}

Department of Botany, Institute of Biology, Pedagogical University, Podchorążych 2, 30-084 Kraków, Poland, e-mail: bbk@up.krakow.pl

\begin{abstract}
In Poland, the largest stretches of abandoned agricultural areas were formed at the end of the 1980s, along western and eastern borders, among others, in Przemyśl Foothills (Pogórze Przemyskie). Therefore, the research on the diversity of plant communities from abandoned agricultural areas as well as main directions and the rate of succession after the cessation of management was undertaken in the vicinity of twelve municipalities in south-eastern Poland. This research revealed that the dominating direction of changes of the abandoned agricultural area vegetation was vanishing of plant groups with segetal and meadow species and spreading of shrub communities. A general increase in the forestation rate of the researched abandoned agricultural areas from $10-40 \%$ of the area in 1970-1971 to about 30-70\% in 2003-2004 may be the evidence of the occurrence intensity of those phenomena.
\end{abstract}

Key words: cessation of management, environmental conditions, fallows, fields, meadows, pastures, succession

\section{Introduction}

At the beginning of $1970 \mathrm{~s}$, the largest number of State Agricultural Farms (Polish: Państwowe Gospodarstwo Rolne-PGR) operated in south-eastern Poland. With the passing of time, they became a serious problem because their production proved to be unprofitable and more expensive than in other regions of Poland (Angerman 1998). After their closure at the beginning of 1990s, land of former farms was sold by the Agricultural Property Agency to private owners. Majority of new owners reintroduced the newly acquired land to agricultural production; however, significantly large territories remained without any farming activity, which resulted in the formation of abandoned agricultural large-areas. The problem of abandoned agricultural large-areas occurred earlier in West European countries and the United States. The appearance of such areas stimulated scientists to study rates, directions and courses of secondary succession processes.

Detailed studies of successional series on abandoned fields (Dubiel 1984; Faliński 1980a, 1980b, 1986) and meadows (Falińska 1989a, 1989b, 1991; Michalik 1990) appeared in Poland only in 1980s and 1990s. Another direction comprised studies relating to various environmental factors that affect vegetation succession processes (Kołos 1991; Kornaś \& Dubiel 1990, 1991; Kotańska 1993a, 1993b; Barabasz 1997; Baryła \& Urban 1999). However, research into the succession occurring on abandoned large-scale lands had not been conducted earlier.

The aim of the research undertaken on abandoned agricultural large-areas in south-eastern Poland was to recognise: (i) diversity of plant communities, (ii) habitat conditions and ecological factors that brought about formation of the present vegetation in this area, (iii) the main directions and rate of succession changes since the cessation of management.

\section{Material and methods}

\subsection{Study area}

The researched abandoned agricultural areas were situated around municipalities located in west (Jawornik Ruski - 49 43' 43" N 22 $12^{\circ}$ ' 13" E, Piątkowa - 49 45' $\left.38^{\prime \prime} \mathrm{N} 22^{\circ} 21^{\prime} 42^{\prime \prime} \mathrm{E}\right)$ and south-east parts of Przemyśl Foothills (Cisowa $-49^{\circ} 42^{\prime}$ ' ' ' N 22 $35^{\prime}$ ' ' E, Olszany

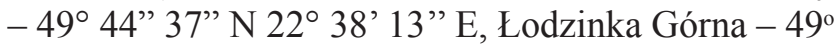
$40^{\prime} 28^{\prime \prime} \mathrm{N}, 22^{\circ} 31^{\prime} 49^{\prime \prime}$ E, Posada Rybotycka - 49 39' 
44" N, 22 36' 56" E, Kopyśno - 49 41' 2" N 22॰ 39' 1 " E, Rybotycze-49० 39'23" N 22०38' 41" E, Huwniki $-49^{\circ} 39^{\prime} 21^{\prime \prime} \mathrm{N} 22^{\circ} 42^{\prime} 16^{\prime \prime} \mathrm{E}$, Leszczyny - 49॰37' $11^{\prime}$ " N $22^{\circ} 40^{\prime} 41^{\prime \prime}$ E, Sopotnik - 49॰36'44" N $22^{\circ} 40^{\prime} 49^{\prime \prime}$ E, Paportno - $49^{\circ} 35^{\prime} 43^{\prime}$ 'N 22 $2^{\circ} 41^{\prime} 32^{\prime \prime}$ E). Leszczyny, Sopotnik and Paportno were the south-easternmost locations. According to the geobotanical division, this territory is included in the Wooded Carpathians District (Karpaty Lesiste) and in the Sub-districts of Przemyśl Foothills (Pogórze Przemyskie) and East-Carpathian Foreland (Przedgórze Wschodniokarpackie) (Wład 1996). In the geomorphological division, it is included in Dynów Foothills (Pogórze Dynowskie) (Klimaszewski \& Starkel 1972) and in the physio-graphic divisionin Przemyśl Foothills (Pogórze Przemyskie) (Kondracki 2000).

Ridge and valley mountains constitute the main components of the area of the Przemyśl Foothills (Janicki 1996). The hills are criss-crossed by numerous stream valleys, with the WE course, which is characteristic for Przemyśl Foothills (Wład 1996). The geological bed is built of Carpathian flysch and Skolska nappe is the tectonic unit of this area. It is made up of overthrust folds running north, covered with Quaternary sediments (Alexandrowicz 1999; Gilewska 1999). The soil cover occurring there consists of soils built of weathered sedimentary compact rocks. Acid and leached soils, brown soils and luvisols, such as: loamy, dusty, clay, less frequently gravel and sandy soils belong to them. The soils cover is varied and alluvial soils, chernozem, muck soils, as well as rendzinas can be found (Prusinkiewicz \& Bednarek 1999). The climate of the area is of transitional, between mountain and lowland, character. It is significantly affected by mountains and modified by the continental influence (Niedźwiedź \& Obrębska-Starkel 1991).

\subsection{Methods}

500 phytosociological relevés were collected in the examined abandoned agricultural areas of various age in summers of 1998-2000 and 2003-2005. The relevés were made by means of the Braun-Blanquet's method. All phytosociological relevés were entered into the phytosociological database TURBOVEG (Hennekens \& Schaminée 2001) and subjected to hierarchical numerical classification (Dzwonko 1977; Sokal \& Rohlf 1981; Gauch 1986; Jongman et al. 1995). The process of classification was carried out twice: based on species abundance according to 6-grade Braun-Blanquet's scale (the value of 0.5 was assumed as + ) and according to species presence/absence (binary scale 0,1 ). In the first case, similarities were calculated using the van der Maarel's formula, in the second case - the formula of Euclidean distance was applied. Grouping was done by means of the Ward's method - minimum variance clustering. The package of MULVA - 5 software was applied for classification (Wildi \& Orlóci 1996). Comparison of the obtained dendrograms made it possible to distinguish groups of similar relevés, regarding both the species abundance and the species presence/absence in communities (Dzwonko \& Loster 1990, 1992).

To characterise habitat conditions for all communities, the weighted means of Ellenberg's indices were calculated in relation to cover-abundance values (light $-\mathrm{L}$, soil moisture $-\mathrm{F}$, soil acidity $-\mathrm{R}$, soil nitrogen $-\mathrm{N}$; Ellenberg et al. 1992), and then the arithmetic means for whole communities were calculated for all relevés. The indicators, such as: general diversity of species $\mathrm{H}$, uniformity $\mathrm{J}$ and domination $\mathrm{C}$ were also compared among the communities (Simpson 1949; Shannon \& Weaver 1963; Pielou 1975).

Analyses of vegetation succession changes were carried out at community scale to observe changes in species composition and species abundance in the same abandoned agricultural area within the period of five years. 65 phytosociological relevés were taken in the "Bobowiska Mount" abandoned agricultural area ("Góra Bobowiska") in Cisowa -35 relevés were made in 2000 and 30 replicated in 2005 and they were numerically ordered by means of Detrended Correspondence Analysis DCA (Hill \& Gauch 1980). The same method was applied to order the species of all relevés taken in this area. The software CANOCO version 3.12 was applied for both processes. Changes of the species coverage index (D) observed in relevés in 2000 and 2005 taken in the abandoned agricultural area "Bobowiska Mount" were also analysed (Tüxen \& Ellenberg 1937).

Apart from that, comparison of floristic composition in all distinguished communities, their abundance, habitat conditions, farming history, stages of overgrowing known from literature were carried out. The comparison allowed the author to determine the main succession directions occurring in south-eastern Poland. The comparative analysis was based, among others, on such works as: Dubiel (1984), Faliński (1986), Falińska (1989a, 1989b), Kornaś and Dubiel (1990, 1991).

Succession changes occurring on landscape scale were illustrated by the comparison of the area share of forest and non-forest communities in the whole investigated area during different periods. Aerial photos taken in the analysed area in the periods of 1970-1971 and 2003-2004, and also cadastral maps of 1983 and 1993 were applied in that case. Surfaces of various categories of land usage were measured planimetrically on the cadastral maps and on air photos by means of AutoCad program. The analysis comprised 22 aerial photos from 1970-1971 and 26 pictures from 2003-2004, showing the state of land usage approximately 10 years after closing State Agricultural Farms (PGR) in the area. It resulted in creating land usage maps of the investi- 
gated areas and measuring the area of particular usage categories in three time periods. Proportion of thickets and forest areas to non-forest areas: fields, meadows and pastures etc., was assumed as an indicator of the succession rate. The nomenclature of plants species followed Mirek et al. (2002) and affiliation of species to syntaxonomic units was determined on the basis of Matuszkiewicz (2007).

\section{Results}

\subsection{Classification of plant communities}

Numeric classification of relevés allowed the author to distinguish 16 types of communities:

Class: Epilobietea angustifolii R. Tx. et Prsg 1950

1. Community with Calamagrostis epigejos

Class: Artemisietea Lohm., Prsg. et R. Tx. 1950

2. Community with Solidago gigantea

3. Community with Rudbeckia laciniata Order: Glechometalia hederaceae R. Tx. in R. Tx. et Brun-Hool 1975
4. Community with Urtica dioica

Class: Molinio-Arrhenatheretea R. Tx. 1937

5. Community Cirsium arvense-Elymus repens

6. Pine thickets (with meadow species in herbs layer)

7. Birch-hornbeam thickets (with meadow species in herbs layer)

Order: Arrhenatheretalia Pawł. 1928

Alliance: Arrhenatherion (Br.-B1. 1925) Koch 1926

8. Arrhenatheretum elatioris (Br.-B1. 1919) Oberd. 1952 (A. medioeuropaeum)

Arrhenatheretum elatioris:
a. variant with Angelica sylvestris
b. variant with Prunus spinosa-Crataegus monogyna
c. variant with Phleum pratense
d. poor variant

A. e. brizetosum mediae:
a. dry variant
b. periodically wet variant

9. Community with Vicia tetrasperma

10. Community Hypericum perforatum-Torilis japonica
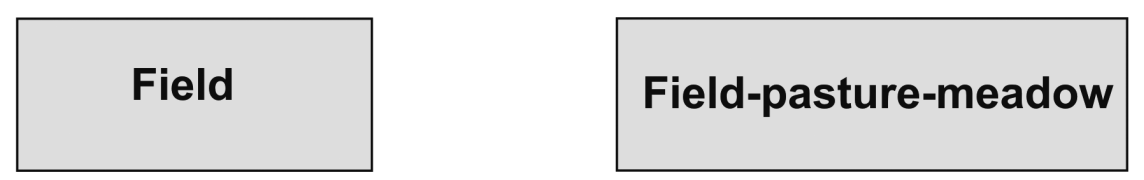

Pasture-meadow
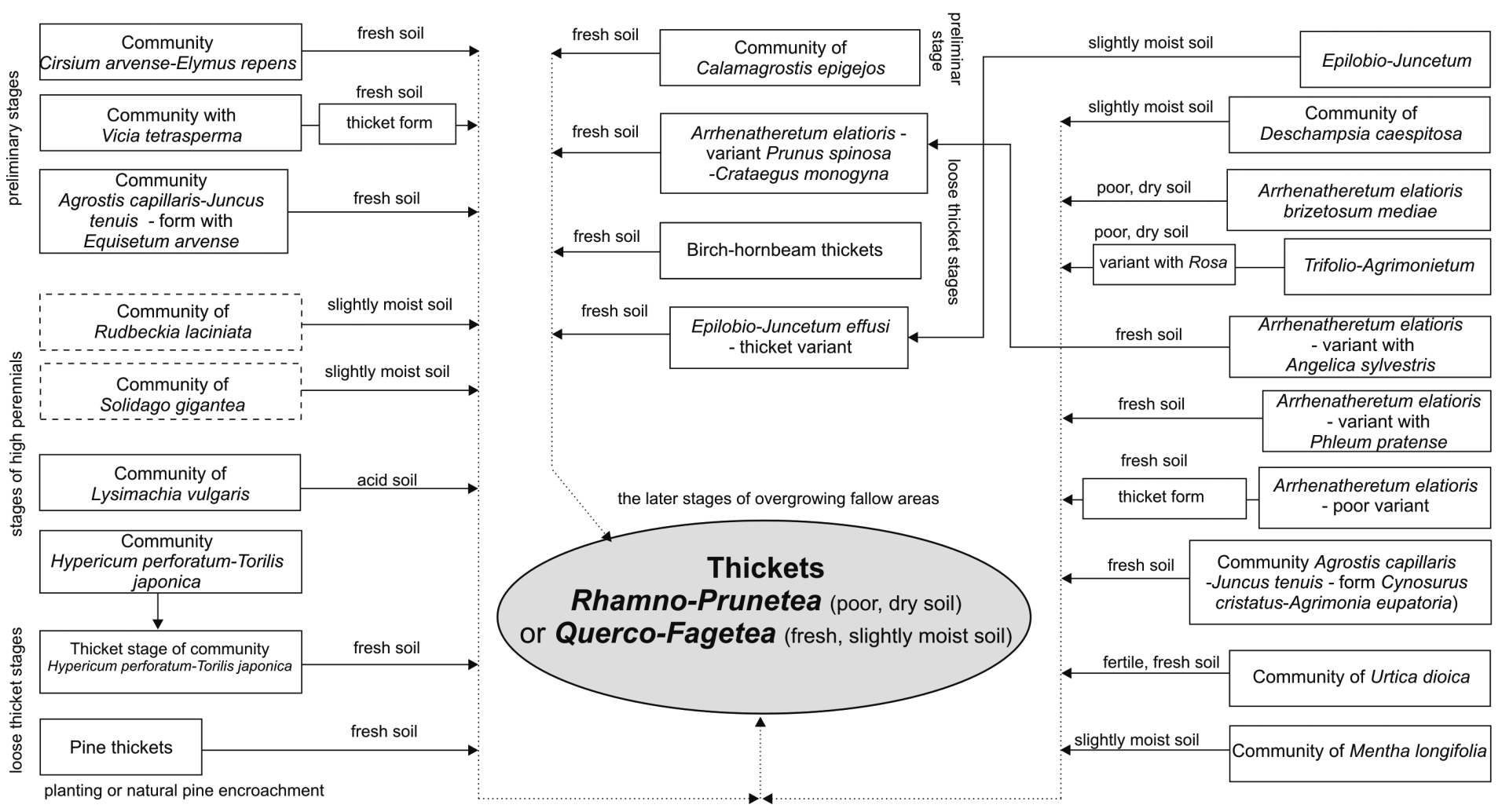

Fig. 1. Relationship between plant communities and the type of fallow land on the abandoned, large-size agricultural areas in south-eastern Poland (Przemyśl Foothills - Pogórze Przemyskie)

Explanations: dashed line boxes - communities documented with a small number of relevés, the dotted line - the presumed direction of succession 
Table 1. Averages and ranges of Ellenberg's indicator values for communities occurring in the studied abandoned agricultural areas

\begin{tabular}{|c|c|c|c|c|c|}
\hline \multirow[b]{2}{*}{ Type of community } & \multirow[b]{2}{*}{$\begin{array}{l}\text { Number } \\
\text { of relevés }\end{array}$} & \multicolumn{4}{|c|}{ Average Ellenberg's indicator values } \\
\hline & & $\begin{array}{l}\text { Light } \\
\text { (L) }\end{array}$ & $\begin{array}{l}\text { Soil } \\
\text { moisture } \\
\text { (F) }\end{array}$ & $\begin{array}{l}\text { Soil pH } \\
\text { (R) }\end{array}$ & $\begin{array}{l}\text { Soil } \\
\text { nitrogen } \\
(\mathrm{N})\end{array}$ \\
\hline Community of Calamagrostis epigejos & 11 & $\begin{array}{c}6.83 \\
6.59-7.08\end{array}$ & $\begin{array}{c}5.14 \\
4.71-5.63\end{array}$ & $\begin{array}{c}6.45 \\
5.45-7.14\end{array}$ & $\begin{array}{c}5.37 \\
4.45-6.09\end{array}$ \\
\hline Community of Solidago gigantea & 3 & $\begin{array}{c}6.95 \\
6.82-7.04\end{array}$ & $\begin{array}{c}5.70 \\
5.61-5.86\end{array}$ & $\begin{array}{c}5.04 \\
4.31-6.14\end{array}$ & $\begin{array}{c}5.87 \\
5.24-6.62\end{array}$ \\
\hline Community of Rudbeckia laciniata & 3 & $\begin{array}{c}6.85 \\
6.71-7.12\end{array}$ & $\begin{array}{c}6.33 \\
5.88-6.92\end{array}$ & $\begin{array}{c}6.68 \\
6.48-6.78\end{array}$ & $\begin{array}{c}6.23 \\
5.83-6.81\end{array}$ \\
\hline Community of Urtica dioica & 17 & $\begin{array}{c}6.72 \\
6.47-7.05\end{array}$ & $\begin{array}{c}5.73 \\
5.30-6.34\end{array}$ & $\begin{array}{c}6.81 \\
6.25-7.06\end{array}$ & $\begin{array}{c}7.57 \\
6.61-8.05\end{array}$ \\
\hline $\begin{array}{l}\text { Community Cirsium arvense-Elymus } \\
\text { repens }\end{array}$ & 18 & $\begin{array}{c}7.00 \\
6.66-7.46\end{array}$ & $\begin{array}{c}5.45 \\
4.82-6.43\end{array}$ & $\begin{array}{c}6.60 \\
5.85-7.19\end{array}$ & $\begin{array}{c}6.23 \\
5.44-7.12\end{array}$ \\
\hline Pine thickets & 17 & $\begin{array}{c}6.73 \\
6.45-6.95\end{array}$ & $\begin{array}{c}5.29 \\
4.86-6.06\end{array}$ & $\begin{array}{c}6.02 \\
5.21-7.04\end{array}$ & $\begin{array}{c}5.24 \\
4.27-5.66\end{array}$ \\
\hline Birch-hornbeam thickets & 17 & $\begin{array}{c}6.65 \\
6.09-7.02\end{array}$ & $\begin{array}{c}5.52 \\
5.14-6.08\end{array}$ & $\begin{array}{c}5.42 \\
4.30-6.56\end{array}$ & $\begin{array}{c}5.28 \\
4.74-5.62\end{array}$ \\
\hline $\begin{array}{l}\text { Arrhenatheretum elatioris - variant with } \\
\text { Angelica sylvestris }\end{array}$ & 19 & $\begin{array}{c}6.95 \\
6.79-7.27\end{array}$ & $\begin{array}{c}5.05 \\
4.76-5.43\end{array}$ & $\begin{array}{c}6.76 \\
6.33-7.08\end{array}$ & $\begin{array}{c}5.45 \\
4.83-6.10\end{array}$ \\
\hline $\begin{array}{l}\text { A. e. } t \text {. - variant Prunus spinosa-Crataegus } \\
\text { monogyna }\end{array}$ & 19 & $\begin{array}{c}6.83 \\
6.64-7.07\end{array}$ & $\begin{array}{c}5.12 \\
4.68-5.32\end{array}$ & $\begin{array}{c}6.46 \\
5.83-7.16\end{array}$ & $\begin{array}{c}5.47 \\
4.95-5.91\end{array}$ \\
\hline A. e. t. - variant with Phleum pratense & 16 & $\begin{array}{c}6.85 \\
6.58-7.08\end{array}$ & $\begin{array}{c}5.41 \\
5.10-5.64\end{array}$ & $\begin{array}{c}6.24 \\
5.61-6.83\end{array}$ & $\begin{array}{c}5.86 \\
5.47-6.45\end{array}$ \\
\hline A. e.t. - poor variant & 23 & $\begin{array}{c}6.83 \\
6.51-7.14\end{array}$ & $\begin{array}{c}5.48 \\
4.90-6.07\end{array}$ & $\begin{array}{c}5.68 \\
4.56-6.43\end{array}$ & $\begin{array}{c}5.44 \\
4.11-6.16\end{array}$ \\
\hline A. e. brizetosum mediae & 32 & $\begin{array}{c}6.90 \\
6.68-7.37\end{array}$ & $\begin{array}{c}4.92 \\
3.97-5.59\end{array}$ & $\begin{array}{c}6.00 \\
4.33-6.77\end{array}$ & $\begin{array}{c}4.09 \\
3.15-4.88\end{array}$ \\
\hline Community with Vicia tetrasperma & 32 & $\begin{array}{c}6.92 \\
6.66-7.25\end{array}$ & $\begin{array}{c}5.15 \\
4.64-5.59\end{array}$ & $\begin{array}{c}6.40 \\
6.04-6.94\end{array}$ & $\begin{array}{c}5.46 \\
4.79-6.36\end{array}$ \\
\hline $\begin{array}{l}\text { Community Hypericum perforatum-Torilis } \\
\text { japonica }\end{array}$ & 24 & $\begin{array}{c}6.72 \\
6.50-7.04\end{array}$ & $\begin{array}{c}5.54 \\
5.27-5.90\end{array}$ & $\begin{array}{c}6.32 \\
4.92-7.10\end{array}$ & $\begin{array}{c}5.92 \\
5.22-6.42\end{array}$ \\
\hline $\begin{array}{l}\text { Thicket stage of community Hypericum } \\
\text { perforatum-Torilis japonica }\end{array}$ & 23 & $\begin{array}{c}6.69 \\
6.20-7.00\end{array}$ & $\begin{array}{c}5.56 \\
5.19-6.13\end{array}$ & $\begin{array}{c}6.46 \\
5.74-7.18\end{array}$ & $\begin{array}{c}5.89 \\
5.44-6.47\end{array}$ \\
\hline $\begin{array}{l}\text { Community Agrostis capillaris-Juncus } \\
\text { tenuis }\end{array}$ & 32 & $\begin{array}{c}6.83 \\
6.43-7.08\end{array}$ & $\begin{array}{c}5.39 \\
4.93-6.21\end{array}$ & $\begin{array}{c}5.80 \\
5.03-6.68\end{array}$ & $\begin{array}{c}5.11 \\
4.41-5.86\end{array}$ \\
\hline Community of Mentha longifolia & 22 & $\begin{array}{c}6.76 \\
6.44-7.12\end{array}$ & $\begin{array}{c}6.28 \\
5.73-7.05\end{array}$ & $\begin{array}{c}7.10 \\
5.55-7.74\end{array}$ & $\begin{array}{c}6.21 \\
4.93-6.72\end{array}$ \\
\hline Community of Deschampsia caespitosa & 16 & $\begin{array}{c}6.66 \\
6.44-6.95\end{array}$ & $\begin{array}{c}5.60 \\
5.11-6.13\end{array}$ & $\begin{array}{c}6.35 \\
5.46-6.89\end{array}$ & $\begin{array}{c}4.84 \\
4.15-5.83\end{array}$ \\
\hline community of Lysimachia vulgaris & 9 & $\begin{array}{c}6.44 \\
6.03-6.91\end{array}$ & $\begin{array}{c}6.01 \\
5.45-6.22\end{array}$ & $\begin{array}{c}4.80 \\
4.00-5.44\end{array}$ & $\begin{array}{c}5.20 \\
4.59-6.28\end{array}$ \\
\hline Epilobio-Juncetum & 18 & $\begin{array}{c}6.87 \\
6.60-7.18\end{array}$ & $\begin{array}{c}6.09 \\
5.50-6.82\end{array}$ & $\begin{array}{c}5.63 \\
4.91-6.77\end{array}$ & $\begin{array}{c}5.19 \\
4.46-5.93\end{array}$ \\
\hline Epilobio-Juncetum - thicket variant & 28 & $\begin{array}{c}6.78 \\
6.48-7.10\end{array}$ & $\begin{array}{c}5.52 \\
4.92-6.10\end{array}$ & $\begin{array}{c}5.89 \\
4.83-6.62\end{array}$ & $\begin{array}{c}5.63 \\
4.81-6.45\end{array}$ \\
\hline Trifolio-Agrimonietum & 18 & $\begin{array}{c}7.05 \\
6.87-7.29\end{array}$ & $\begin{array}{c}4.61 \\
4.04-5.14\end{array}$ & $\begin{array}{c}7.01 \\
6.57-7.54\end{array}$ & $\begin{array}{c}4.41 \\
3.70-5.31\end{array}$ \\
\hline
\end{tabular}


Thicket stadium community Hypericum perforatum-Torilis japonica

11. Community Agrostis capillaris-Juncus tenuis

Order: Trifolio fragiferae-Agrostetalia stoloniferae R. Tx. 1970

Alliance: Agropyro-Rumicion crispi Nordh. 1940 em. R. Tx. 1950

12. Community with Mentha longifolia Order: Molinietalia Koch 1926

13. Community with Deschampsia caespitosa Alliance: Filipendulion ulmariae Segal 1966

14. Community with Lysimachia vulgaris Alliance: Calthion R. Tx. 1936 em. Oberd. 1957

15. Epilobio-Juncetum effusi Oberd. 1957 Epilobio-Juncetum effusi
a. wet variant
b. dry
c. thicket variant

Class: Trifolio-Geranietea sanguinei Th. Müller 1962

Alliance:Trifolion medii Th. Müll. 1961

16. Trifolio-Agrimonietum eupatoriae Th. Müll. 1961

Three of them represent associations of Arrhenatheretum elatioris, Epilobio-Juncetum, Trifolio-Agrimonietum, known from literature.

Comparison of mean values of the Ellenberg's indicator proved that the communities belonged to moderately photophilous ones. Due to soil nitrogen occurrence, they remained in limits between poor and rich in nitrogen; however, most of them were at the medium level. The soil $\mathrm{pH}$ was weak acid, close to neutral or neutral. Most of the soils belonged to fresh or, less frequently, wet ones. Only Arrhenatheretum elatioris brizetosum mediae and Trifolio-Agrimonietum occurred on dry soils (Table 1).

Table 2. Values of general diversity $(\mathrm{H})$, uniformity $(\mathrm{J})$ and dominance $(\mathrm{C})$ indicators for communities of abandoned, large-size agricultural lands in south-eastern Poland (Przemyśl Foothills)

\begin{tabular}{|c|c|c|c|c|}
\hline Type of community & $\begin{array}{l}\text { Average number of } \\
\text { species in relevé }\end{array}$ & $\mathrm{H}$ & $\mathrm{J}$ & $\mathrm{C}$ \\
\hline Community with Calamagrostis epigejos & $32 ; n=11$ & 4.17 & 0.71 & 0.05 \\
\hline Community with Solidago gigantea & $20 ; n=3$ & 3.02 & 0.73 & 0.10 \\
\hline Community with Rudbeckia laciniata & $27 ; n=3$ & 3.70 & 0.79 & 0.05 \\
\hline Community with Urtica dioica & $18 ; n=17$ & 3.27 & 0.57 & 0.12 \\
\hline Community Cirsium arvense-Elymus repens & $31 ; \mathrm{n}=18$ & 4.28 & 0.68 & 0.03 \\
\hline Pine thickets & $50 ; \mathrm{n}=17$ & 4.67 & 0.69 & 0.01 \\
\hline Birch-hornbeam thickets & $41 ; n=17$ & 4.54 & 0.69 & 0.02 \\
\hline $\begin{array}{l}\text { Arrhenatheretum elatioris - variant with Angelica } \\
\text { sylvestris }\end{array}$ & $44 ; n=19$ & 4.56 & 0.68 & 0.02 \\
\hline $\begin{array}{l}\text { A. e. t. - variant Prunus spinosa-Crataegus } \\
\text { monogyna }\end{array}$ & $47 ; n=19$ & 4.63 & 0.68 & 0.01 \\
\hline A. e. $t$. - variant with Phleum pratense & $42 ; n=16$ & 4.18 & 0.64 & 0.02 \\
\hline A. e. t. - poor variant & $30 ; n=23$ & 4.00 & 0.61 & 0.03 \\
\hline A. e. brizetosum mediae & $52 ; \mathrm{n}=32$ & 4.85 & 0.65 & 0.01 \\
\hline Community with Vicia tetrasperma & $42 ; n=32$ & 4.57 & 0.63 & 0.01 \\
\hline $\begin{array}{l}\text { Community Hypericum perforatum-Torilis } \\
\text { japonica }\end{array}$ & $47 ; n=24$ & 4.62 & 0.66 & 0.01 \\
\hline $\begin{array}{l}\text { Thicket stage of community Hypericum } \\
\text { perforatum-Torilis japonica }\end{array}$ & $46 ; n=23$ & 4.67 & 0.67 & 0.02 \\
\hline Community Agrostis capillaris-Juncus tenuis & $46 ; n=32$ & 4.58 & 0.63 & 0.02 \\
\hline Community with Mentha longifolia & $33 ; n=22$ & 4.33 & 0.66 & 0.03 \\
\hline Community with Deschampsia caespitosa & $44 ; n=16$ & 4.46 & 0.68 & 0.02 \\
\hline Community with Lysimachia vulgaris & $28 ; n=9$ & 3.92 & 0.71 & 0.04 \\
\hline Epilobio-Juncetum & $44 ; n=18$ & 4.53 & 0.68 & 0.02 \\
\hline Epilobio-Juncetum - thicket variant & $44 ; n=28$ & 4.61 & 0.64 & 0.02 \\
\hline Trifolio-Agrimonietum & $54 ; n=18$ & 4.82 & 0.70 & 0.01 \\
\hline
\end{tabular}

Explanations: the highest and the lowest values are marked in grey, $\mathrm{n}$ - the number of relevés for a given community 
Table 3. Values of Pearson's correlation ( $r$ ) between DCA axes, environmental variables and average Ellenberg's indicator values calculated for phytosociological relevés of the fallow field "Bobowiska Mount" in Cisowa

\begin{tabular}{lcccc}
\hline \multirow{2}{*}{ Characteristics } & \multicolumn{2}{c}{$\begin{array}{c}\text { DCA based on species } \\
\text { abundance }\end{array}$} & \multicolumn{2}{c}{$\begin{array}{c}\text { DCA based on species } \\
\text { presence/absence }\end{array}$} \\
\cline { 2 - 5 } & Axis I & Axis II & Axis I & Axis II \\
\hline Exposure & -0.03 & -0.13 & -0.07 & -0.13 \\
Herbaceous cover & -0.04 & -0.09 & -0.13 & -0.21 \\
Maximum height of herbs & 0.47 & -0.07 & 0.56 & -0.02 \\
Bryophytes cover & -0.24 & -0.31 & -0.10 & -0.20 \\
Shrubs and trees cover & 0.59 & -0.04 & 0.74 & -0.32 \\
Maximum height of shrubs and trees & 0.55 & -0.04 & 0.78 & -0.06 \\
Number of species in relevé & -0.11 & -0.23 & -0.12 & -0.25 \\
Ellenberg indicator values: & & & & \\
Light L & -0.23 & -0.17 & -0.36 & -0.01 \\
Soil moisture F & -0.17 & -0.12 & -0.33 & -0.07 \\
Soil reaction $(\mathrm{pH}) \mathrm{R}$ & -0.15 & -0.10 & -0.29 & -0.01 \\
Soil nitrogen N & -0.19 & -0.12 & -0.31 & -0.04 \\
\hline
\end{tabular}

Explanation: the highest correlation values are marked in grey
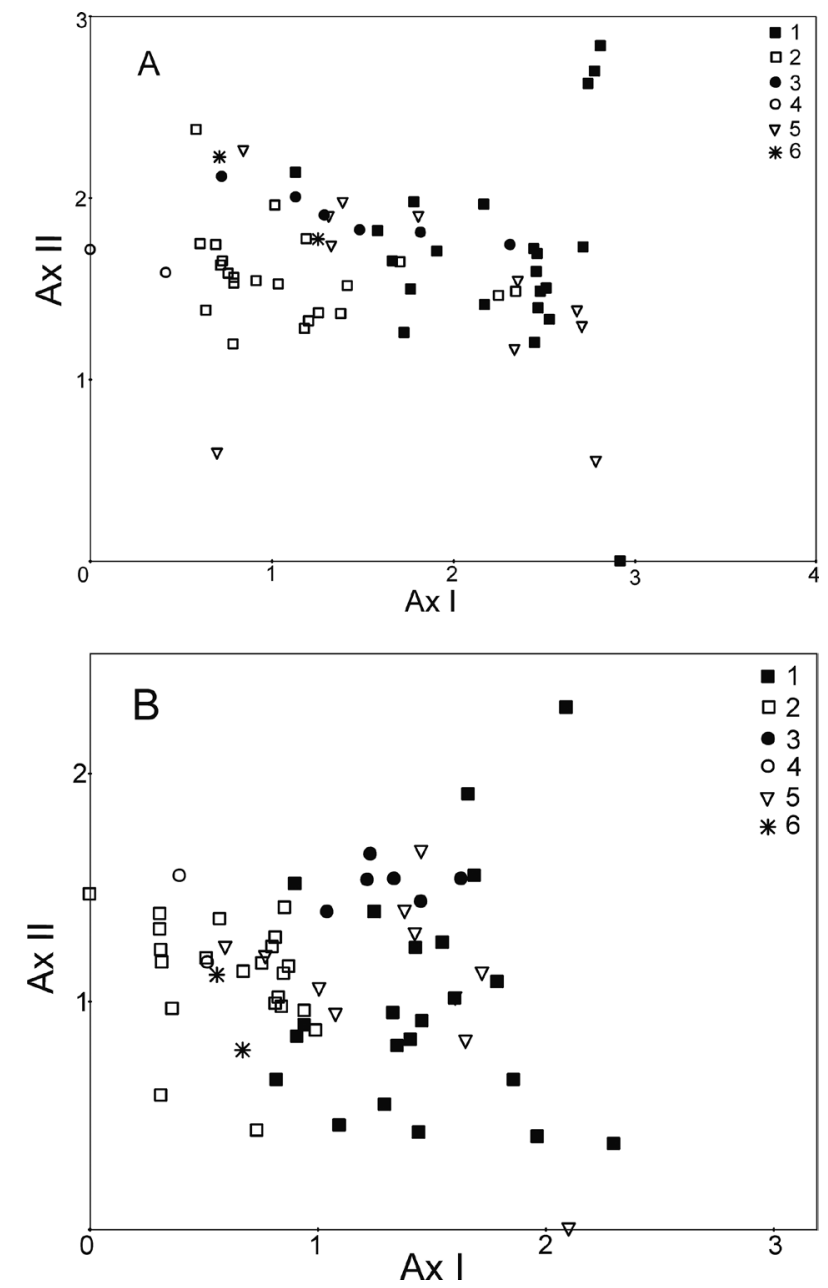

A relatively high value of Shannon-Weaver index $(\mathrm{H})$ in all communities indicated the species richness, which proved dynamic changes in vegetation in those areas (Table 2). Succession changes in the abandoned fields proceeded from communities representing initial stages of succession, characterised by segetal species occurrence, through communities with a high share of tall perennial plants to communities representing early grass-shrub stages with species of Molinio-Arrhenatheretea still dominating in the herbs layer. The succession directions in the abandoned meadows and pastures started from communities representing the species composition typical for neglected phytocoenoses of fresh meadows, pastures and forest-edge communities, through communities with dominating tall herbal vegetation to shrub-herbal ones (Fig. 1).

\subsection{Numerical ordination of relevés}

Numerical ordination of relevés made in 2000 and 2005 at Cisowa in the abandoned agricultural area "Bobowiska Mount" ("Góra Bobowiska") along two first DCA axes enabled the author to arrange communities from the least shrub-covered with a relatively low

Fig. 2. Ordination of phytosociological relevés made in "Bobowiska Mount" (Cisowa) in 2000 and 2005 according to I and II DCA axes; A - based on species abundance, B - based on species presence/absence

Explanations: 1 - thicket stage of community Hypericum perforatum-Torilis japonica (most of relevés made in 2005), 2 - community Hypericum perforatumTorilis japonica (all relevés made in 2000), 3 - pine thickets (all relevés made in 2005), 4 - community Cirsium arvense-Elymus repens (all relevés made in 2000), 5 - transitional stages (most of relevés made in 2005), 6 - Epilobio-Juncetum - thicket variant (all relevés made in 2000) 
herb layer (the left side of the diagram) to the most densely covered by tree species with tall perennial plants dominating in the herb layer (the right side of the diagram) - Fig. (2). Ordination of species arranged them from weeds connected with farming and pasture management recorded in 2000 to plants typical for perennial fallow lands with majority of phanerophytes occurring in 2005 (Table 3, Fig. 3).

A decrease in the coverage index (D) of all segetal species, majority of meadow species and several ruderal ones were observed in the relevés made at "Bobowiska Mount" in 2005 when compared to the state of 2000.
During the same time, an increase in the coverage index of shrub species, some forest and forest-edge species occurred there (Table 4). 9 segetal species, 12 meadow ones became extinct in the area in the period of 5 years, while 3 ruderal species, 11 shrub and 4 forest ones appeared.

\subsection{Analysis of cadastral maps, aerial photos}

Analysis of cadastral maps and aerial photos showed that the forest-shrub succession was the dominating direction of vegetation changes in the abandoned agricultural large-areas leading to a decline of groups with

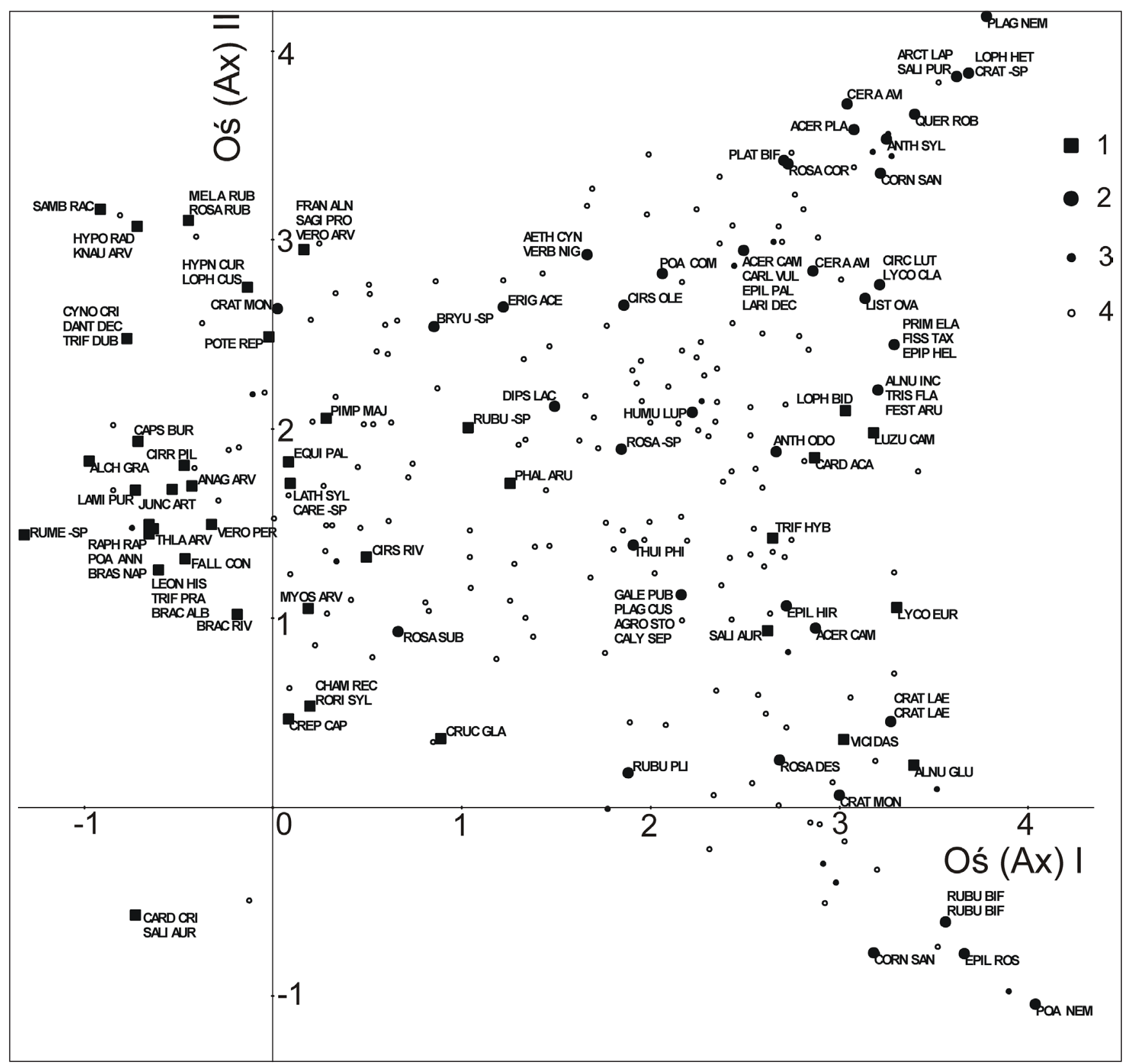

Fig. 3. Ordination of species from phytosociological relevés made in "Bobowiska Mount" (Cisowa) in 2000 and 2005 according to I and II DCA axes, based on species abundance

Explanations: 1 - species found only in 2000, 2 - species found only in 2005, 3 - shrubs found in 2000 and 2005, but in different layers, 4 - common herbaceous species found in 2000 and 2005 
segetal and meadow species and propagation of shrub communities (Table 5).

Comparison of percentage cover in various usage categories carried out at three time points proved a significant growth in the forestation rate from $10 \%-40 \%$ of the area in 1970-1971 to approximately $30-70 \%$ - in 2003-2004 (Table 6). The biggest changes were found in three localities: Cisowa (Fig. 4), Posada Rybotycka and Piątkowa.

Table 4. Cover indices (D) of species from six ecological/sociological groups occurring in phytosociological relevés of "Bobowiska Mount" (Cisowa) in 2000 and 2005

\begin{tabular}{|c|c|c|c|c|c|}
\hline \multirow{3}{*}{ Groups of species } & \multicolumn{2}{|c|}{ Cover index } & \multirow{3}{*}{ Groups of species } & \multicolumn{2}{|c|}{ Cover index } \\
\hline & \multicolumn{2}{|c|}{ Years } & & \multicolumn{2}{|c|}{ Years } \\
\hline & 2000 & 2005 & & 2000 & 2005 \\
\hline Segetal & & & Meadow cont. & & \\
\hline Equisetum arvense & 995.14 & 329.33 & Holcus lanatus & 333.71 & 663.67 \\
\hline Elymus repens & 703.14 & 4.00 & Lysimachia nummularia & 251.71 & 0.33 \\
\hline Vicia tetrasperma & 127.43 & 73.00 & Arrhenatherum elatius & 194.00 & 18.67 \\
\hline Tussilago farfara & 66.00 & 1.67 & Daucus carota & 184.00 & 130.00 \\
\hline Myosotis arvensis & 23.43 & 0.00 & Taraxacum officinale & 182.00 & 21.33 \\
\hline Lathyrus tuberosus & 15.14 & 0.67 & Potentilla anserina & 165.71 & 76.00 \\
\hline Convolvulus arvensis & 0.57 & 18.33 & Mentha longifolia & 158.29 & 1.33 \\
\hline Xerothermic sward & & & Cirsium palustre & 150.57 & 36.00 \\
\hline Hypericum perforatum & 490.86 & 41.33 & Rumex crispus & 121.71 & 24.00 \\
\hline Senecio jacobaea & 159.14 & 5.00 & Achillea millefolium & 110.57 & 211.67 \\
\hline Euphorbia cyparissias & 94.86 & 1.33 & Mentha arvensis & 90.00 & 1.33 \\
\hline Trifolium campestre & 51.71 & 0.67 & Poa pratensis & 89.43 & 4.33 \\
\hline Clinopodium vulgare & 16.29 & 54.67 & Juncus effusus & 84.29 & 97.33 \\
\hline Trifolium medium & 3.14 & 35.00 & Galium mollugo & 84.86 & 620.00 \\
\hline Origanum vulgare & 2.29 & 256.33 & Phleum pratense & 69.43 & 9.00 \\
\hline Vicia sepium & 2.29 & 35.33 & Lathyrus pratensis & 65.14 & 2.00 \\
\hline Thickets & & & Festuca rubra & 51.14 & 0.33 \\
\hline Salix caprea (b) & 66.29 & 660.67 & Potentilla reptans & 50.57 & 0.00 \\
\hline Rosa canina (b) & 1.43 & 19.67 & Juncus articulatus & 50.29 & 0.00 \\
\hline Pyrus communis (b) & 0.86 & 38.00 & Stachys palustris & 34.29 & 24.67 \\
\hline Rosa canina var. corym. (b) & 0.00 & 17.33 & Angelica sylvestris & 16.86 & 220.67 \\
\hline Rubus bifrons (b) & 0.00 & 16.67 & Festuca pratensis & 16.29 & 19.00 \\
\hline Calamagrostis epigejos & 1688.86 & 2302.67 & Carex hirta & 15.43 & 51.33 \\
\hline Senecio ovatus & 1.14 & 738.00 & Phragmites australis & 0.29 & 17.00 \\
\hline Fragaria vesca & 64.57 & 77.33 & & & \\
\hline Carex spicata & 0.86 & 17.33 & Ruderal & & \\
\hline Forest & & & Cirsium arvense & 1250.57 & 635.33 \\
\hline Betula pendula (b) & 0.29 & 144.33 & Erigeron anпuиs & 804.29 & 480.67 \\
\hline Salix cinerea (b) & 0.00 & 210.00 & Torilis japonica & 740.00 & 122.33 \\
\hline Pinus sylvestris (b) & 0.00 & 103.00 & Tanacetum vulgare & 179.71 & 187.00 \\
\hline Rubus hirtus (b) & 0.00 & 16.67 & Urtica dioica & 148.57 & 91.00 \\
\hline Acer pseudoplatanus (c) & 3.43 & 21.33 & Epilobium parviflorum & 136.29 & 0.33 \\
\hline Carex remota & 15.71 & 0.33 & Eupatorium cannabinum & 86.00 & 278.67 \\
\hline Dryopteris filix-mas & 14.29 & 0.67 & Epilobium montanum & 58.86 & 153.67 \\
\hline Athyrium filix-femina & 14.29 & 0.33 & Picris hieracioides & 50.86 & 164.33 \\
\hline Carex sylvatica & 3.43 & 19.00 & Geranium columbinum & 46.29 & 2.00 \\
\hline Salvia glutinosa & 0.29 & 35.00 & Artemisia vulgaris & 44.29 & 3.00 \\
\hline Meadow & & & Dipsacus sylvestris & 32.29 & 4.00 \\
\hline Agrostis capillaris & 518.57 & 247.00 & Cirsium decussatum & 30.29 & 1.67 \\
\hline Dactylis glomerata & 505.43 & 305.67 & Epilobium adnatum & 14.86 & 36.33 \\
\hline Ranunculus repens & 467.71 & 119.67 & Dipsacus laciniatus & 0.00 & 50.33 \\
\hline
\end{tabular}

Explanation: the increased index values in 2005 compared to 2000 are marked in grey 
Table 5. Comparison of the area [ha] of different land use categories in the studied areas of south-eastern Poland (Przemyśl Foothills) from years 1970/1971, 1983 and 1993, 2003/2004

\begin{tabular}{|c|c|c|c|}
\hline Category of use/Years & $1970 / 1971$ & 1983 and 1993 & $2003 / 2004$ \\
\hline Field & 1160.48 & 903.43 & 317.05 \\
\hline Field/pasture & - & 1.85 & - \\
\hline Barren field & - & - & 179.53 \\
\hline Barren field sporadically mown & - & - & 304.19 \\
\hline Barren field/loose thickets & - & - & 316.41 \\
\hline Meadow & 201.04 & 216.86 & 4.18 \\
\hline Meadow-pasture & 152.09 & - & 0.84 \\
\hline Meadow/field & - & 4.90 & - \\
\hline Barren meadow/loose thickets & - & 2.20 & - \\
\hline Barren meadow & - & - & 81.54 \\
\hline Barren meadow sporadically mown & - & - & 58.57 \\
\hline Barren meadow/loose thickets & - & - & 26.27 \\
\hline Pasture & 520.82 & 626.30 & 1.63 \\
\hline Pasture/loose thickets & 152.67 & 71.72 & 0.38 \\
\hline Barren pasture & - & - & 163.19 \\
\hline Barren pasture sporadically grazed & - & - & 1.86 \\
\hline Barren pasture sporadically mown & - & - & 142.64 \\
\hline Barren pasture/loose thickets & - & - & 181.03 \\
\hline Orchard & - & 73.68 & 19.41 \\
\hline Orchard/pasture & - & 11.71 & - \\
\hline Orchard/barren pasture & - & - & 5.30 \\
\hline Orchard/barren field & - & - & 25.32 \\
\hline Loose thickets & 63.61 & 44.79 & 89.09 \\
\hline Loose thickets /field & - & 2.40 & - \\
\hline Forest & 331.45 & 376.97 & 508.96 \\
\hline Forest/loose thickets & 1.61 & - & 49.63 \\
\hline Tree plantation & - & - & 20.10 \\
\hline Area prepared for artificial tree plantation & - & - & 9.90 \\
\hline Wasteland/baulks & 13.19 & 3.12 & 7.74 \\
\hline Total & 2596.95 & $2339.94 *$ & 2514.78 \\
\hline
\end{tabular}

Explanations: * - only the fragments owned by the State Agricultural Farms were included, which resulted in the lower land area than indicated by aerial photographs

\section{Discussion}

\subsection{Causes of plant community diversity in aban- doned agricultural areas}

Formation of all communities in the investigated area resulted from the exclusion of land from agricultural usage. The diversity of species composition of the communities was influenced by four main factors: type, age of the abandoned agricultural area, habitat conditions and communities directly adjacent to the area.

The type of abandoned agricultural area is a consequence of agricultural management carried out for many years and it affects the diversity of the species composition of communities (Meisel 1978; Reif \& Lösch 1979; Dubiel 1984; Faliński 1986; Myster \& Picket 1990; Tscharntke et al. 2011; Sojneková \& Chytrý 2015). The last crop residue may remain in plant communities for about 10 years after ceasing the cultivation. Remnants of other agricultural activities appear in the composition of plant communities occurring in the abandoned agricultural areas (Picket \& Cadenasso 2005). In the case of the study area, patches of Arrhenatheretum elatioris variant with Phleum pratense developed as a result of meadow regeneration by undersowing of pasturable grass in the former usage areas. Such method of regeneration is applied in pastures and meadows, as it allows maintenance of high yields and good quality fodder (Baryła \& Urban 1999).

Patches of Epilobio-Juncetum association were another example of remnants of the previous, not necessarily proper, farming practices. They developed as a result of intensive grazing, without appropriate conservation treatments (Fig. 1). Rushes, an important element of such type of pasture, do not belong to species preferred by cattle and sheep. When intensive defoliation of fodder species occurs, they may colonize the habitat without any restraints (Nowiński 1967; Barabasz 1997). The 


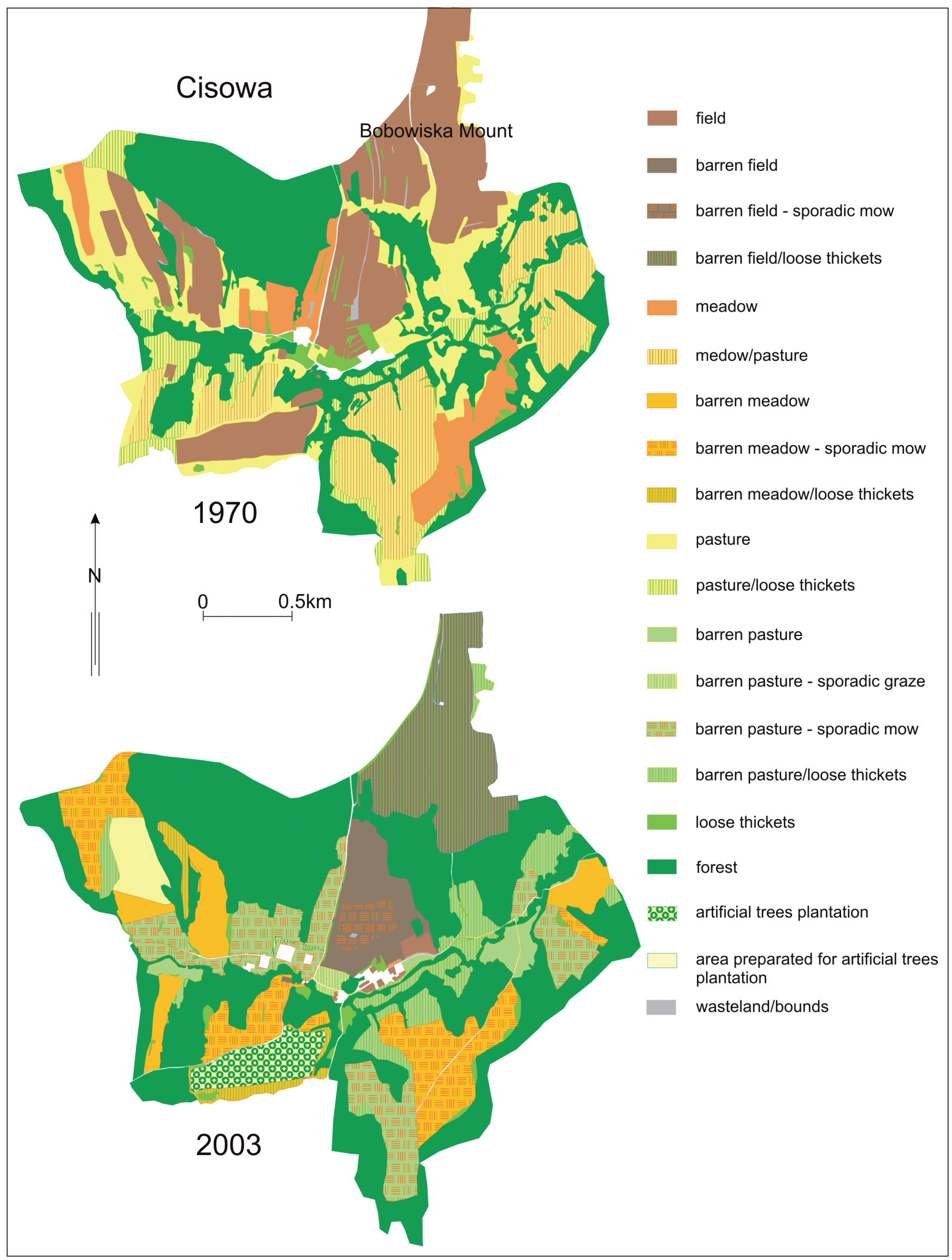

Fig. 4. Land use types in the vicinity of the village of Cisowa in 1970 and 2003, in the areas of former State Agricultural Farms 
Table 6. Percentage participation of forest, shrubs and non-forest areas on the studied abandoned agricultural lands in south-eastern Poland (Przemyśl Foothills), in the years: 1970-1971, 2003-2004, 1983 and 1993

\begin{tabular}{|c|c|c|c|}
\hline \multirow{2}{*}{ Village } & \multirow[b]{2}{*}{ Year } & \multicolumn{2}{|c|}{ Area $[\%]$} \\
\hline & & $\begin{array}{l}\text { Forest and } \\
\text { shrub area }\end{array}$ & $\begin{array}{c}\text { Non forest } \\
\text { area }\end{array}$ \\
\hline \multirow[t]{3}{*}{ Cisowa } & 1970 & 39.96 & 60.04 \\
\hline & 1993 & 46.63 & 53.37 \\
\hline & 2003 & 63.48 & 36.52 \\
\hline \multirow[t]{3}{*}{ Huwniki } & 1970 & 13.89 & 96.11 \\
\hline & 1993 & 17.00 & 83.00 \\
\hline & 2003 & 35.01 & 64.99 \\
\hline \multirow[t]{3}{*}{ Jawornik R. } & 1970 & 11.83 & 88.17 \\
\hline & 1993 & 19.25 & 90.75 \\
\hline & 2003 & 44.70 & 55.30 \\
\hline \multirow[t]{3}{*}{ Kopyśno } & 1971 & 15.51 & 94.49 \\
\hline & 1993 & 16.71 & 93.29 \\
\hline & 2003 & 37.48 & 62.52 \\
\hline \multirow[t]{3}{*}{ Leszczyny } & 1971 & 43.99 & 56.01 \\
\hline & 1983 & 25.08 & 74.92 \\
\hline & 2003 & 46.89 & 53.11 \\
\hline \multirow[t]{3}{*}{ Łodzinka Gr. } & 1970 & 28.18 & 71.82 \\
\hline & 1993 & 22.61 & 77.39 \\
\hline & $2003 / 2004$ & 44.01 & 55.99 \\
\hline \multirow[t]{3}{*}{ Olszany } & 1970 & 16.40 & 83.60 \\
\hline & 1983 & 28.83 & 71.17 \\
\hline & 2003 & 35.46 & 64.54 \\
\hline \multirow[t]{3}{*}{ Piątkowa } & 1970 & 17.72 & 82.28 \\
\hline & 1993 & 12.72 & 87.28 \\
\hline & 2003 & 64.50 & 35.50 \\
\hline \multirow[t]{3}{*}{ Posada R. } & 1970 & 16.82 & 79.91 \\
\hline & 1993 & 65.51 & 34.49 \\
\hline & 2003 & 69.69 & 30.31 \\
\hline \multirow[t]{3}{*}{ Rybotycze } & 1971 & 16.82 & 93.18 \\
\hline & 1993 & 14.95 & 95.05 \\
\hline & 2003 & 31.52 & 68.48 \\
\hline
\end{tabular}

Explanation: the major changes are marked in grey

lack of conservation treatments contributed also to the formation of communities with Deschampsia caespitosa (Fig. 1). Such community develops in the areas where water and oxygen relations are not regulated and they continue to deteriorate due to the lack of proper usage (Le Brun et al. 1949).

The period of fallowing is another factor having influence on plant community diversity in abandoned lands (Faliński 1980a, 1980b, 1986; Falińska 1989a, 1989b). According to Dubiel (1984), three stages of succession can be distinguished in fallow fields, depending on their age and composition of the dominant species: stage I - with dominance of Cirsium arvense and Elymus repens, which occur in the fallow period, i.e. in the first or second year after termination of the agricultural usage, stage II - with Agrostis capillaris and Holcus mollis dominance occurring in the third - fourth year of the fallowing, stage III - with dominance of high perennials, e.g. Solidago virgaurea and Hieracium umbellatum (or others) occurring in the fifth year of fallowing. Studies in the south-eastern Poland (Przemyśl Foothills) showed that communities occurring there constituted different age stages of fallows overgrowing (Fig. 1). The Cirsium arvense-Elymus repens community with meadow plants and arable weeds in the species presence developed in the old fields. It corresponded to the earliest stage of Wierzbanówka Valley (Dolina Wierzbanówki) in southern Poland (Dubiel 1984). There was also a post-agricultural form (with Equisetum arvense) of Agrostis capillaris-Juncus tenuis community there, but with a smaller share of Holcus mollis. The high perennials stage was represented by a community with Lysimachia vulgaris. Tall perennials dominated in the community, like in the fifth year stage from Wierzbanówka Valley, and a three-layer structure of green growth could be observed there. The Hypericum perforatum-Torilis japonica community also referred to the stage of tall perennial plants, which was characterized by the occurrence of several species co-dominating or dominating in different patches. The relevés made again in the patches of Hypericum perforatum-Torilis japonica communities after a 5 -year period contained a layer of shrubs, whose maximum coverage could reach up to $85 \%$. A reduction of species abundance among the former dominants could be observed in the herbs layer. This was a following stage of succession of the abovementioned communities, which evolved in the study area about 10-12 years after cessation of agricultural usage (Figs. 1-2, Table 4).

According to Falińska (1989a, 1989b, 1991), shrub and herbaceous species start to invade abandoned meadows 3 years after ceasing the agricultural usage. As a result, about 10 years after abandonment, herbaceous stages with first representatives of willow trees occur and after further 10-15 years - scrub stages form. Certain similarities can be found comparing the results of Falińska's research with the results obtained in Przemyśl Foothills (Fig. 1). Such communities as: Epilobio-Juncetum, Arrhenatherum elatioris variant with Phleum pratense, A. e. brizetosum mediae, were characterized by a typical floristic composition for the meadow-pasture phytocoenoses. They represented early initial stages of succession. Significant dominance of high herbaceous plants appeared in some meadowpasture communities (community with Urtica dioica or with Mentha longifolia). They were probably herbaceous stages, which had their optimum development 10 years after the area abandonment. Shrub species dominance, which occurred in the meadows about 10-15 years after abandonment, was accompanied by 
a reduction of pasturable species and increase of high herbaceous plants abundance. This could be already observed, for example, in some patches of the EpilobioJuncetum shrub stage.

The greatest diversity and species richness in the abandoned lands in Przemysl Foothills were recorded in communities occurring in areas of lower water availability. Patches of Arrhenatheretum elatioris brizetosum mediae and Trifolio-Agrimonietum were characterized by the greatest species richness and the species growing there confirmed dry nature of the substrate (Tables 1-2). Many species occurring in those communities, especially Festuco-Brometea and Trifolio-Geranietea classes, tolerated water deficit, due to physiological and morphological adaptations. In this case, light availability was a factor restraining plant growth, because all meadow-sward species tolerate shade worse than periodical water deficit (Knappová et al. 2012).

The situation was different in groups with hygrophilous species, such as Rudbeckia laciniata community, the community with Mentha longifolia and EpilobioJuncetum (Table 1). In such places, water shortages may cause regression of hygrophilous plants and spreading of mesophilous ones. An overdry variant of EpilobioJuncetum and a dry form of a community with Mentha longifolia were good examples of such situations. When longer periods of reduced water availability occurred, the amount of hygrophilous species from the Calthion alliance and the Molinietalia order decreased in typical patches of those phytocoenoses. Species of the Arrhenatheretalia order, preferring a lower level of soil moisture, started spreading in their place. Nevertheless, such phenomena occur gradually and are most often caused by lowering of the groundwater level, not only by periodical water shortages (Kornaś \& Dubiel 1990, 1991; Kotańska 1993a, 1993b).

Soil fertility is an important factor influencing species composition in communities. High content of nutrients in soil, especially nitrogen, causes dominance of nitrophilous species highly productive in terms of plant biomass (Weiner 1990; Kornaś \& Dubiel 1990; 1991; Bobbink et al. 1998; Bakker \& Berendse 1999; Shmith et al. 2002; Walker et al. 2004). The phenomenon could be observed in a few communities in the abandoned areas in Przemyśl Foothills (e.g., communities with Rudbeckia laciniata, Mentha longifolia, or Cirsium arvense-Elymus repens community), but it became most apparent in the community with Urtica dioica (Tables 1-2). Patches of those phytocoenoses belonged to the poorest as far as the species composition was concerned (Table 2). Nettle, indicator of soils rich in nitrogen (Ellenberg et al. 1992), was the dominant species there. Densely growing individuals of Urtica dioica overshadowed other species, therefore, their occurrence was restricted mostly to the edges of patches.
4.2. Succession processes in abandoned agricultural areas

Termination of usage or maintenance activities constitute factors disturbing the structure of current vegetation on abandoned agricultural areas (Kornaś 1990; Kornaś \& Dubiel 1990, 1991; Barabasz 1994; Barabasz-Krasny 2002). According to Drury and Nisbet (1973), those factors may be treated as causes of high environmental stress that initiate dynamic processes of vegetation. Undoubtedly, the cessation of usage played a key role in initiating vegetation succession in the abandoned agricultural large-areas in south-eastern Poland.

In meadow and pasture areas, vegetation is characterised by large density and, thus, by lack of empty space for colonization (Harper 1977; Gross \& Werner 1982; Olson \& Richards 1989; Thórhallsdottir 1990). In this case, availability of space is the most important factor limiting dynamics of the vegetation. However, after cessation of mowing, species with clonal growth may complete their full development unperturbed, causing changes in quantitative and spatial relations in plant communities (Brzosko 2000; Albert et al. 2014). As a result of changes in habitat conditions and dying of individuals previously inhabiting a given space, gaps are created in the sward. Those gaps are quickly colonized by species from other habitats that use any resulting disruption in the structure of communities (Falińska 1989a, 1989b, 1991).

The situation develops differently on former arable lands, where the problem of empty space for colonisation in the initial stages of the succession is practically not important (Dubiel 1984; Jírová et al. 2012). In that case, the dynamic processes of vegetation depend on the seed-bank preserved in soil and on the seed inflow from the adjacent areas (Stearns \& Likens 2002). According to Dobrzański (2009), there might be from several dozens to several hundred millions arable weed seeds in the arable layer of a field an area of 1 ha. In unfavourable conditions, the seeds of certain species may survive even several dozens of years without losing their germination capacity (Aldrich 1984; van Acker 2002). Even if diversity of the seed-bank in soil was not preserved due to agrotechnical measures carried out for many years in the abandoned agricultural fields of Przemyśl Foothills, the inflow of propagules of the inhabiting species was still provided by the adjacent forest and meadow areas.

Termination of farming activities influences the type and number of available resources of the habitat (Faliński 1986; Falińska 1989a, 1989b; Kornaś 1990; Kotańska 1993b). Long-term research of the succession of abandoned agricultural fields have shown that some species exist long before, as well as after the domination period, and other species, that have been expected to 
be eliminated, still remain in some plant communities. Arboreal anemochorous species are frequently early colonists, in spite of their domination in the further stages of succession (Pickett \& Cadenasso 2005). The results of research of the abandoned agricultural large-areas of south-eastern Poland also confirmed it. There were species in communities of the abandoned agricultural field of "Bobowiska Mount" ("Góra Bobowiska") whose coverage indices (D) distinctly increased in 2005 in comparison with the state of 2000 e.g. Calamagrostis epigejos, Senecio ovatus, Holcus lanatus, Angelica sylvestris, Eupatorium cannabinum, Picris hieracioides and others (Table 4). Most of them appeared in the early stages of abandoning, but with a significantly smaller coverage. Anemochorous species of trees, such as Betula pendula, Salix caprea and Pinus sylvestris, were also present in the earlier stages of abandoned agricultural areas in 2000. They were distributed in smaller quantity and, in the case of pine, only in the herb layer. Some of them entered the layer of shrubs, mainly in pine shrubs and the shrub stage of the plant community of Hypericum perforatum-Torilis japonica not earlier than in 2005 (Fig. 3, Tables 3-4). A group of segetal species that already had a low rate of coverage in 2000 became completely extinct in five years' time (Chamomilla recutita, Lamium purpureum, Veronica persica, Anagalis arvensis, Fallopia convolvulus, Raphanus raphanistrum, Thlaspi arvense, Myosotis arvensis). It is thought that the species directly connected with crops disappear most rapidly, although there are exceptions to this rule (Dubiel 1984). In some patches, the segetal species still remained; however, their rate of coverage became significantly lower, e.g.: Elymus repens, Vicia tetrasperma, Lathyrus tuberosus (Table 4).

Appearance and disappearance of species on persitently abandoned agricultural areas leads to transformations in entire plant communities, which, consequently, causes general changes of the landscape. Landscape changes caused by succession processes are currently very well visible on the abandoned agricultural largeareas of south-eastern Poland (Tables 5-6). It applies to all the localities included in the research but, especially, to Posada Rybotycka, Piątkowa and Cisowa (Fig. 4). The percentage of forest and scrub surface there distinctly increased, at the expense of crop fields and grasslands. All previous usage categories disappeared and abandoned or sporadically used areas appeared. As a result of demographic and economic changes, connected with the drop of profitability of agricultural production, the process of re-naturalisation could be observed on the study area. The phenomenon caused, among others, diminishing of the mosaic character of the Przemyśl Foothills landscape (Janicki 1998, 2005).

\section{Conclusions}

The research on vegetation on abandoned agricultural large-areas of south-eastern Poland showed the scale and complexity of the occurring succession processes. Simultaneously, it illustrated the richness and diversity of successional stages occurring there - altogether 16 types of communities were distinguished $(i)$. The cessation of traditional management methods, which initiated the change of environmental conditions and turned on succession exerted the most important influence on the composition of present-day communities. An important role in the course of succession was also played by: the type of abandoned agricultural area, habitat conditions and the communities directly adjacent to the area (ii). The disappearance of meadow-pasture communities and the spread of scrub and forest groupings was the dominant direction in the dynamics of vegetation on that area (iii).

Acknowledgements. I would like to thank Prof. Zbigniew Dzwonko (Institute of Botany, Jagiellonian University, Poland) for valuable comments and discussions, Prof. Eugeniusz Dubiel (Institute of Botany, Jagiellonian University, Poland) for patience and help in syntaxonomic assessments. 


\section{References}

Albert Á. J., Kelemen A., Valkó O., Miglécz T., Csecserits A., Rédei T., DeÁK B., Tóthmérész B. \& TöröK P. 2014. Secondary succession in sandy old-fields: a promising example of spontaneous grassland recovery. Appl. Veg. Sci. 17: 214-224. DOI: 10.1111/avsc.12068

AlDRICH R. J. 1984. Crop production practices and weeds. In: R. J. AldRICH (ed.). Weed crop ecology. Principles in weed management, pp. 373-397, Breton Publ., North Scituate, MA.

Alexandrowicz S. W. 1999. Budowa geologiczna. In: L. Starkel (ed.). Geografia Polski - Środowisko Przyrodnicze, pp. 221-243. Wyd. Nauk. PWN, Warszawa.

Angerman P. G. 1998. Bieszczadzkie refleksje. Przyroda. Silva rerum - Ekologiczne miscellanea. Biblioteka "Zielonych Brygad" 27: 380-383.

BAKKer J. P. \& Berendse F. 1999. Constraints in the restoration of ecological diversity in grassland and heather communities. Trends Ecol. Evol. 14: 63-68. DOI: 10.1016/S0169-5347(98)01544-4

BARABASz B. 1994. Wpływ modyfikacji tradycyjnych sposobów gospodarowania na przemiany roślinności łąk z klasy Molinio-Arrhenatheretea. Wiad. Bot. 38(1-2): 85-94.

BARABASz B. 1997. Zmiany roślinności łąk w północnej części Puszczy Niepołomickiej w ciągu 20 lat. Studia Nat. 43: 1-99.

Barabasz-Krasny B. 2002. Sukcesja roślinności na łąkach, pastwiskach i nieużytkach porolnych Pogórza Przemyskiego. Fragm. Flor. Geobot. Polon. Suppl. 4: 1-82.

BARYŁA R. \& URBAn D. 1999. Kierunki zmian w zbiorowiskach trawiastych w wyniku ograniczenia i zaniechania użytkowania rolniczego na przykładzie łąk Poleskiego Parku Narodowego. Folia Univ. Agricult. Stetin., Agricult. 197(75): 25-30.

Bobbink R., Hornung M. \& Roelofs J. G. M. 1998. The effect of air-borne nitrogen pollutants on species diversity in natural and semi-natural European vegetation - a review. J. Ecol. 86: 717-738. DOI: 10.1046/j.13652745.1998.8650717.x

Brzosko E. 2000. Zmiany liczebności populacji roślin o różnych strategiach reprodukcyjnych w procesie sukcesji. Wiad. Bot. 44 (3-4): 13-22.

DoBRZAŃski A. 2009. Biologiczne i agrotechniczne aspekty regulowania zachwaszczenia. Ekspertyza. Instytut Warzywnictwa Skierniewice, AgEngPol, p. 24. (www. agengpol.pl).

Drury W.H. \& Nisbet I. C. T. 1973. Succession. J. Arnold Arbor. Harv. Univ. 54: 331-368.

Dubiel E. 1984. Dolina Wierzbanówki: 5. Rozwój roślinności na odłogach. Zesz. Nauk. Uniw. Jagiell. Prace Bot. 12: $97-112$.

Dzwonko Z. 1977. The use of numerical classification in phytosociology. Fragm. Flor. Geobot. 23(3-4): 327-343.

Dzwonko Z. \& Loster S. 1990. Vegetation differentiation and secondary succession on a limestone hill in southern Poland. J. Veg. Sci. 1: 615-622. DOI: $10.2307 / 3235567$
Dzwonko Z. \& Loster S. 1992. Zróżnicowanie roślinności i wtórna sukcesja $\mathrm{w}$ murawowo-leśnym rezerwacie Skołczanka koło Krakowa. Ochr. Przyr. 50: 33-64.

Ellenberg H., Weber H., Dull R., Wirth V., Werner W. \& Paulissen D. 1992. Zegerverte von Pflanzen in Mitteleuropa. Scripta Geobot. 18: 1-258.

FALIŃSKI J. B. 1980a. Vegetation dynamics and sex structure of the population of pioneer dioecious woody plants. Vegetatio 43: 23-38. DOI: 10.1007/BF00121014

FALIŃSKI J. B. 1980b. Changes in the sex- and age-ratio in population of pioneer dioecious woody species (Juniperus, Populus, Salix) in connection with the course of vegetation succession in abandoned farmlands. Ekol. Pol. 28(3): 327-365.

FALIŃSKi J. B. 1986. Sukcesja roślinności na użytkach porolnych jako przejaw dynamiki ekosystemu wyzwolonego spod długotrwałej presji antropogenicznej. Cz. I. Podstawy teoretyczne i prezentacja wybranej serii sukcesji wtórnej. Wiad. Bot. 30(1): 25-50.

FALIŃSKA K. 1989a. Plant population processes in the course of forest succession in abandoned meadows. I. Variability and diversity of floristic combinations, and biological mechanisms of species turnover. Acta Soc. Bot. Pol. 58(3): 439-465.

FALIŃSKA K. 1989b. Plant population processes in the course of forest succession in abandoned meadows. II. Demography of succession promoters. Acta Soc. Bot. Pol. 58(3):467-491.

FALIŃSKA K. 1991. Sukcesja jako efekt procesów demograficznych roślin. In: B. FALIŃSKi (ed.). Dynamika roślinności i populacji roślinnych. Phytocoenosis 3 (N.S.) Sem. Geobot. 1: 43-67.

GaUCH H.G. 1986. Multivariate analysis in community ecology. $\mathrm{x}+298$ pp. Cambridge University Press, Cambridge.

Gilewska S. 1999. Rzeźba. In: L. Starkel (ed.). Geografia Polski - Środowisko Przyrodnicze, pp. 243-288. Wyd. Nauk. PWN, Warszawa.

Gross K. L. \& Werner P. A. 1982. Colonizing abilities of four "biennial" plant species in various vegetation patch types: implications for distributions in a successional sere. Ecology 63: 921-931.

Harper J. L. 1977. Population biology of plants. xxiv + 892 pp. Academic Press, London, New York, San Francisco.

Hennekens S. M. \& Schaminée J. H. J. 2001. TURBOVEG, a comprehensive data base management system for vegetation data. J. Veg. Sci. 12: 589-591. DOI: $10.2307 / 3237010$

Hill M. \& Gauch H.G. 1980. Detrended correspondence analysis: an improved ordination technique. Vegetatio 42: 47-58. DOI: 10.1007/BF00048870

Jírová A., KLaudisová A. \& Prach K. 2012. Spontaneous restoration of target vegetation in old-fields in a central European landscape: a repeated analysis after three decades. Appl. Veg. Sci. 15: 245-252. DOI: 10.1111/j.1654-109X.2011.01165.x 
JANICKI R. 1996. Pogórze Karpackie - niedoceniany brat Bieszczadów. Wyd. Towarzystwa Popierania Twórczości. Ezop (dodatek) - Miesięcznik "Na przykład" 4(32): 1-2.

JANICKI R. 1998. Zmiany zaludnienia i użytkowania ziemi w Parku Krajobrazowym Pogórza Przemyskiego. Przemiany krajobrazu naturalnego Polski. Acta Geogr. Lodz. 74: 83-95.

JANICKI R. 2005. Intensywność przemian krajobrazu Parku Krajobrazowego Pogórza Przemyskiego w warunkach zmniejszonej antropopresji. Ph. D. Thesis, 165 pp. Instytut Nauk o Ziemi Uniwersytetu M. Curie-Skłodowskiej, Lublin.

Jongman R., ter BraAk C. J. F. \& van Tongeren O. R. F. 1995. Data analysis in community and landscape ecology. $1, x+299$ pp. Pudoc, Wageningen.

Klimaszewski M. \& Starkel L. 1972. Karpaty Polskie. In: M. Klimaszewski (ed.). Geomorfologia Polski, Polska południowa - góry i wyżyny, pp. 21-151. Wyd. Nauk. PWN, Warszawa.

Knappová J., Hemrová L. \& Münzbergová Z. 2012. Colonization of central European abandoned fields by dry grassland species depends on the species richness of the source habitats: a new approach for measuring habitat isolation. Landsc. Ecol. 27: 97-108. DOI 10.1007/s10980-011-9680-5

KoŁos A. 1991. Oddziaływanie sąsiedztwa lasu na przebieg sukcesji na porzuconych łąkach w Dolinie Narewki. Phytocoenosis 3(N.S.), Sem. Geobot. 1:119-126.

Kondracki J. 2000. Geografia regionalna Polski. 440 pp. Wyd. Nauk. PWN, Warszawa.

KoRnAŚ J. 1990. Jak i dlaczego giną nasze zespoły roślinne. Wiad. Bot. 34(2): 7-16.

Kornaś J. \& DubIEL E. 1990. Przemiany zbiorowisk łąkowych Ojcowskiego Parku Narodowego w ostatnim trzydziestoleciu. Prądnik. Prace Muz. Szafera 2: 97-106.

Kornaś J. \& Dubiel E. 1991. Land use and vegetation changes in hay-meadow in the Ojców National Park during last thirty years. Veröf. Geobot. Inst. ETH, Zürich, Stiftung Rübel 106: 209-231.

Kotańska M. 1993a. Dynamic of wet meadow communities (Calthion alliance) in the Wierzbanówka Valley in 1976-1988. Fragm. Flor. Geobot. 38(2): 593-619.

KotańsKa M. 1993b. Response of wet meadows of the Calthion alliance to variations of weather and management practices - a thirteen-years study of permanent plots. Studia Nat. 40: 3-47.

Le Brun J., Noirfalise A., Heinemann P. \& van den Berghen C. 1949. Les associations végétales de Belgique. Bull. Soc. Roy. Bot. Belg. 82: 105-207.

Matuszkiewicz W. 2007. Przewodnik do oznaczania zbiorowisk roślinnych Polski. In: J. B. FALiński (ed.). Vademecum Geobotanicum, 3, 537 pp. Wyd. Nauk. PWN, Warszawa.

Meisel K. 1978. Vegetationsentwicklung auf Brachflächen. Acta Bot. Slov. Ser. A. 3: 311-318.

Michalik S. 1990. Przemiany roślinności łąkowej w toku sukcesji wtórnej na stałej powierzchni badawczej w Ojcowskim Parku Narodowym. Prądnik. Prace Muz. Szafera 2: 149-159.
Mirek Z., Pięroś-Mirkowa H., ZająC A. \& Zając M. 2002. Flowering plants and pteridophytes of Poland. A checklist. In: Z. Mirek (ed.). Biodiversity of Poland, 1, 442 pp. W. Szafer Institute of Botany, Polish Academy of Sciences, Kraków.

Myster R. W. \& Picket S. T. A. 1990. Initial conditions, history, and successional pathways in ten contrasting old fields. Am. Midl. Nat. 124: 231-238.

Niedźwiedź T., Obrębska-Starkel B. 1991. Klimat. In: I. Dynowska \& M. MACIEJEWski (eds.). Dorzecze górnej Wisły, 1, 341 pp. Wyd. Nauk. PWN, WarszawaKraków.

NowiŃski M. 1967. Polskie zbiorowiska trawiaste i turzycowe. 284 pp. Wyd. PWRiL, Warszawa.

Olson B. E. \& Richards J. H. 1989. Crested wheatgrass growth and replacement following fertilization, thinning, and neighbor plant removal. J. Range Manage. 42(2): 93-97.

Pickett S. T. A. \& Cadenasso M. L. 2005. Vegetation dynamics. In: E. vAN DER MAAREL (ed.). Vegetation Ecology, pp. 172-198, Blackwell, Oxford.

Pielou E. C. 1975. Ecological diversity. viii + 165 pp. WileyInterscience, New York.

Prusinkiewicz Z. \& Bednarek R. 1999. Gleby. In: L. Starkel (ed.). Geografia Polski - Środowisko Przyrodnicze, pp. 373-396. Wyd. Nauk. PWN, Warszawa.

ReIF A. \& Lösch R. 1979. Sukzessionen auf Sozialbrachflächen und in Jungfichtenpflanzungen im nördlichen Spessart. Mitt. Florist.-Soziol. Arbeitsgem. 21: 75-96.

Shannon C. E. \& WeAver W. 1963. The mathematical theory of communication. 144 pp. Urbana, Univ. of Illinois Press.

Simpson E. H. 1949. Measurement of diversity. Nature 163: 688. DOI: $10.1038 / 163688 \mathrm{a} 0$

Shmith R. S., Shiel R. S., Millward D., Corkhill P. \& SANDRESON R. A. 2002. Soil seed bank and effects of meadow management on vegetation change in a 10 year meadow field trial. J. Appl. Ecol. 39(2): 279-293. DOI: $10.1046 /$ j.1365-2664.2002.00715.x

Sojneková M. \& Chytrý M. 2015. From arable land to species-rich semi-natural grasslands: Succession in abandoned fields in a dry region of central Europe. Ecol. Eng. 77: 373-381. DOI: 10.1016/j.ecoleng. 2015.01.042

Sokal R. R. \& RohlF F. J. 1981. Biometry. The principles and practice of statistics in biological research. xviii +859 pp. Freeman, New York.

Stearns F. \& Likens G. E. 2002. One hundred years of recovery of pine forest in northern Wisconsin. Am. Midl. Nat. 148: 2-19. DOI: 10.1674/0003-0031

Tscharntke T., Batáry P. \& Dormann C. F. 2011. Set-aside management: how do succession, sowing patterns and landscape context affect biodiversity? Agric. Ecosyst. Environ. 143: 37-44. DOI: 10.1016/j. agee.2010.11.025

ThórhallsdottiR T. E. 1990. The dynamics of a grassland community: a simultaneous investigation of spatial and temporal heterogeneity at various scales. J. Ecol. 78: 884-908. DOI: 10.2307/2260941

TÜXEN R. \& Ellenberg H. 1937. Der systematische und ökologische Gruppenvert. Ein Beitrag zur Begriffobildung 
und Methodik der Pflanzensoziologie. Mitt. Florist.Soziol. Arbeitsgem. 3: 171-184.

Walker K. J., Stevens P. A., Stevens D. P., Mountford J. O., Manchester S. J. \& Pywell R. F. 2004. Restoration and re-creation of species-rich lowland grassland and land formerly managed for intensive agriculture in the UK. Biol. Conserv. 119: 1-18. DOI: 10.1016/j. biocon.2003.10.020

WeINER J. 1990. Asymmetric competition in plant populations. Trends Ecol. Evol. 5(11): 360-364. DOI: 10.1016/0169-5347(90)90095-U
WiLdi O. \& OrLóci L. 1996. Numerical exploration of community patterns. A guide to use of MULVA-5. 2 ed., 171 pp. SPB Academic Publishing. The Hague.

WŁad P. 1996. Regiony fizyczno-geograficzne okolic Przemyśla. Roczn. Przem. 32(2): 3-41.

VAN ACKer R. C. 2002. Weed biology serves practical weed management. Weed Res. 49: 492-502. DOI: 10.1111/j.1365-3180.2008.00656.x 